
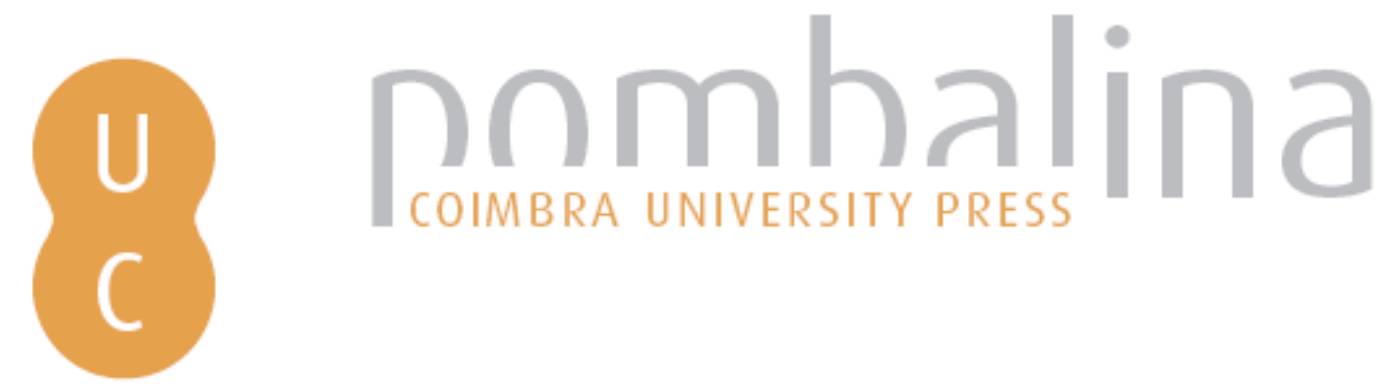

\title{
Carbon dioxide emission on recurrent burnt peat swamp forest in Raja Musa Forest Reserve, Selangor, Malaysia
}

\author{
Autor(es): $\quad$ Nuruddin, Ahmad Ainuddin; Asari, Nur Haifaa' Izwa; Hamid, Hazandy \\ Abdul; Ismail, Mohd Kamil \\ Publicado por: Imprensa da Universidade de Coimbra \\ URL \\ persistente: \\ URI:http://hdl.handle.net/10316.2/44668 \\ DOI: \\ DOI:https://doi.org/10.14195/978-989-26-16-506_151 \\ Accessed : $\quad$ 26-Apr-2023 14:08:44
}

A navegação consulta e descarregamento dos títulos inseridos nas Bibliotecas Digitais UC Digitalis, UC Pombalina e UC Impactum, pressupõem a aceitação plena e sem reservas dos Termos e Condições de Uso destas Bibliotecas Digitais, disponíveis em https://digitalis.uc.pt/pt-pt/termos.

Conforme exposto nos referidos Termos e Condições de Uso, o descarregamento de títulos de acesso restrito requer uma licença válida de autorização devendo o utilizador aceder ao(s) documento(s) a partir de um endereço de IP da instituição detentora da supramencionada licença.

Ao utilizador é apenas permitido o descarregamento para uso pessoal, pelo que o emprego do(s) título(s) descarregado(s) para outro fim, designadamente comercial, carece de autorização do respetivo autor ou editor da obra.

Na medida em que todas as obras da UC Digitalis se encontram protegidas pelo Código do Direito de Autor e Direitos Conexos e demais legislação aplicável, toda a cópia, parcial ou total, deste documento, nos casos em que é legalmente admitida, deverá conter ou fazer-se acompanhar por este aviso.

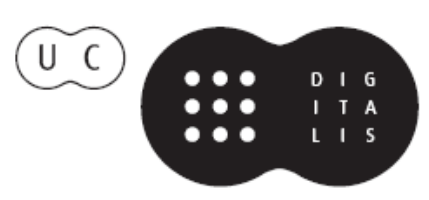




\section{ADVANCES IN}

\section{FOREST FIRE RESEARCH}

\section{8}

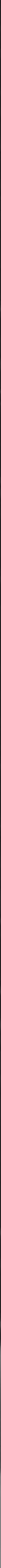


Short contribution - Fire Management

Carbon dioxide emission on recurrent burnt peat swamp forest in Raja Musa Forest Reserve, Selangor, Malaysia

\author{
Ahmad Ainuddin Nuruddin ${ }^{1 *}$; Nur Haifaa’ Izwa Asari ${ }^{2}$, Hazandy Abdul Hamid $^{1}$, and Mohd Kamil Ismail ${ }^{2}$ \\ ${ }^{1}$ Institute of Tropical Forestry and Forest Product, Universiti Putra Malaysia, 43400 Serdang, Selangor, \\ Malaysia \{ainuddin@upm.edu.my*,hazandy@upm.edu.my\} \\ ${ }^{2}$ Faculty of Forestry, University Putra Malaysia, 43400 Serdang, Selangor, Malaysia, \\ \{haifaizwan@gmail.com,mkamil1986@gmail.com\}
}

\begin{abstract}
Peatlands represent globally significant stores of soil carbon that have been accumulating for millennia and currently. However, the human activities have causes degradation which led to increase in forest fire incidences and emissions of green house gases into the atmosphere. However, not musch is known on emissions of green house gases on recurrent burnt peat forest. The objective of this study was to investigate carbon dioxide emission and its relationship with environmnetal factors on recurrent burnt tropical peat swamp forest. This study was conducted on plot which has been experiencing recurrent fires since 1996 in Raja Musa Forest Reserve, Selangor, Malaysia. The carbon diaoxide emission rates in recurrent burnt plot was in the ranges from 2.13 to $8.50 \mu \mathrm{mol} \mathrm{m}^{-2} \mathrm{~s}^{-1}$. The result also showed the variation in relationship between soil $\mathrm{CO}_{2}$ emission across time, weekly and monthly and statistically analysis showed a significant correlation between soil $\mathrm{CO}_{2}$ emission with soil temperature and soil humidity. In conclusion, soil temperature and relative humidity were the factors influencing the soil $\mathrm{CO}_{2}$ variation significantly according to different months.
\end{abstract}

Keywords: Tropical peat samp forest, Carbon dioxide, forest fire

\title{
1. Introduction
}

Tropical peat swamp forests are an important component of the world's wetlands and provide a variety of benefits in the form of timber products, fishery resources, energy, flood mitigation, water supply and groundwater recharge. However, since 1990, 5.1 Mha of the total 15.5 Mha of peatland in the southeast Asia have been deforested, drained and burned while most of the remaining peat swamp forest has been logged intensively (Miettinen and Liew, 2010).

Over the same period there is an increase of tropical peat swamp forest areas that have been converted to oil palm and plywood plantations from 2 to $15 \%$ of the total peatland area. This high rate of conversion has affect the delicate balance of ecosystem process in the area and has led to the draining of the tropical peat swamp coupled with the drought cycle has causes fires in the are Ainuddin and Goh, (2010). The impacts of these fires were haze and release of green house gasses into the atmosphere (Syaufina et al., 2004).

Hence, there is a strong interest in quantifying carbon dioxide emission from unburnt and recurrent tropical peatlands as part of the wider debate on the impacts of tropical land use change on climate change processes.

\section{Methodology}

In this study, sampling was conducted at the latitude of $03^{\circ} 26^{\prime} 08^{~ " N o r t h ~ a n d ~ l o n g i t u d e ~} 101^{\circ} 25^{\prime} 09^{\prime \prime}$ East at Raja Musa Forest Reserve (RMFR), Bestari Jaya Selangor. RMFR covers 23,000 ha and has 
annual rainfall ranged from 1336 to $2673 \mathrm{~mm}$ with high rainfall in November while the lowest in June. RMFR and together with Sungai Karang Forest Reserve are known as North Selangor Peat Swamp Forest (NSPSF).

Plots with $20 \mathrm{~m} \times 20 \mathrm{~m}$ in size that easy for accessibility were chosen in compartment 6.200 small plots were measured with an area of $1 \mathrm{~m} \times 1 \mathrm{~m}$. Three small plots were selected using the random sampling methods which were plots 68, 70 and 151.

Three sampling point were established and soil collars were inserted in a certain depth and the volume of soil covered in the soil collar is determined and leave for 24 hours before data collection to create equilibrium stage and avoid soil disturbance. The offset between the ground and the top edge of the collar were taken for the total volume correction (offset). Next, the measurements of soil CO2 emission were taken using Closed Dynamic Chamber (CDC) (Li-COR 8100 Automated Soil CO $\mathrm{CO}_{2}$ Flux System) with $20 \mathrm{~cm}$ sized. This newly developed fully automated system can measure soil $\mathrm{CO}_{2}$ efflux at one stop over time repeatedly. The data was recorded every five minutes for every observation. 30 seconds from 5 minutes observation is a pre-purge stage functioning to avoid overestimation of $\mathrm{CO}_{2}$ emission caused by the initial accumulation of the gas in the chamber. Other environmental factors also can be measured using Li-COR 8100 such as soil temperature and relative humidity.

\section{Results}

The total soil $\mathrm{CO}_{2}$ efflux in three months showed that there was varied at different months. The diurnal pattern of soil $\mathrm{CO}_{2}$ emission from the three months measurement from 3 August 2016 to 15 October 2016 displaced a mean of 4.26 to $5.09 \mu \mathrm{mol} \mathrm{m}^{-2} \mathrm{~s}^{-1}$ (table 1) that showed different emission from 11.40 a.m. to 2.45 p.m. with nearly similar soil temperature and relative humidity. Soil $\mathrm{CO}_{2}$ efflux showed daily rates of 2.13-5.06, 3.34-5.99 and 3.06-8.50 $\mu \mathrm{mol} \mathrm{m}^{-2} \mathrm{~s}^{-1}$ in August, September and October respectively.

Table 1 - Descriptive statistics of soil $\mathrm{CO}_{2}$ efflux $\left(\mu_{\mathrm{mol} \mathrm{m}}^{-2} \mathrm{~s}^{\boldsymbol{4}}\right)$

\begin{tabular}{cccccc}
\hline Month & Mean & $\begin{array}{c}\text { Standard } \\
\text { Deviation }\end{array}$ & $\begin{array}{c}\text { Standard } \\
\text { Error }\end{array}$ & Minimum & Maximum \\
\hline August & 4.78 & 2.71 & 1.36 & 2.13 & 8.43 \\
September & 4.26 & 0.22 & 0.61 & 3.34 & 5.99 \\
October & 5.09 & 2.97 & 1.72 & 3.06 & 8.5 \\
\hline
\end{tabular}

The result for soil $\mathrm{CO}_{2}$ effluxes is summarized in Figure 1 until Figure 11 for each subplot (subplot 68,70 and 151). The mean soil $\mathrm{CO}_{2}$ efflux in this area was $4.68 \mu \mathrm{mol} \mathrm{m}^{-2} \mathrm{~s}^{-1}$. The scatter plots showed the relationship between the soil $\mathrm{CO}_{2}$ effluxes and time which were measured from $10.40 \mathrm{a} . \mathrm{m}$. until 02.45 p.m.. Even though there are some Figures showed negative relationship but it can be concluded that the soil $\mathrm{CO}_{2}$ flux increases gradually across time as $73 \%$ of the scatter plots showed positive relationship. In addition, soil respiration could be affected by photosynthesis process (Ekblad and Hogberg, 2001). Photosynthesis process was depending on the sunlight as the more sunlight means high in temperature will increased photosynthesis process in plant and this will affect soil respiration. As photosynthesis happen, $\mathrm{CO}_{2}$ will be released. There are some plots that show negative relationship because it probably depends on environmental factors. 


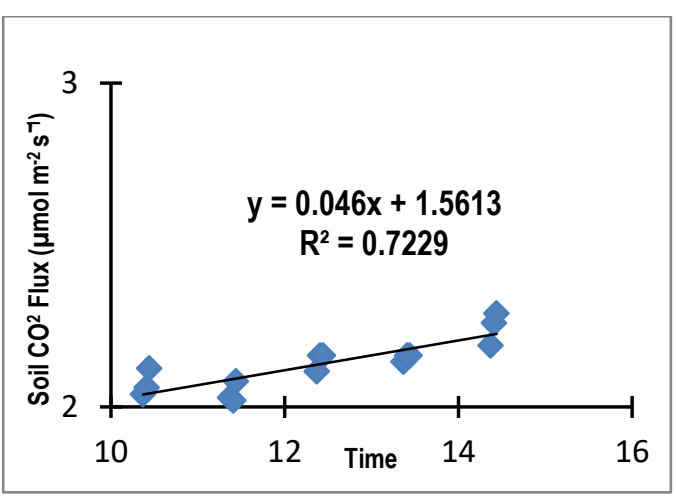

Figure 1 - Soil $\mathrm{CO}_{2}$ flux at plot 151

(03.08.2016)

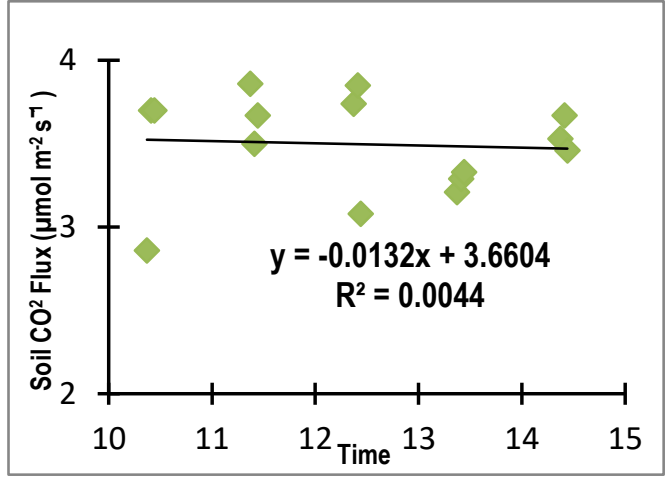

Figure 2 - Soil $\mathrm{CO}_{2}$ Flux at plot 70

$(10.08 .2016)$

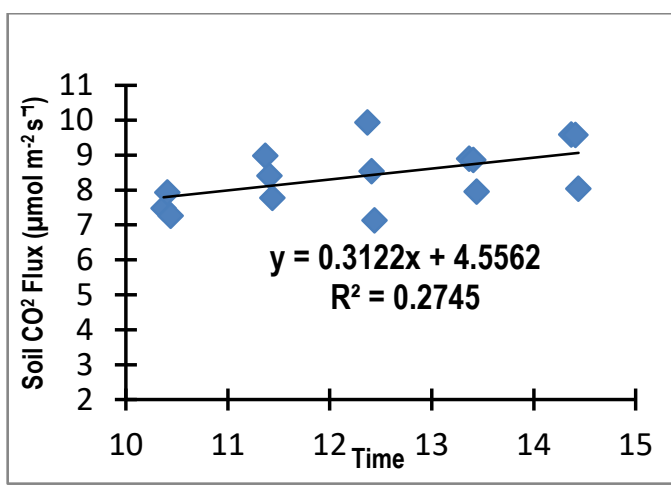

Figure 3 - Soil $\mathrm{CO}_{2}$ Flux at plot 68

$(17.08 .2016)$

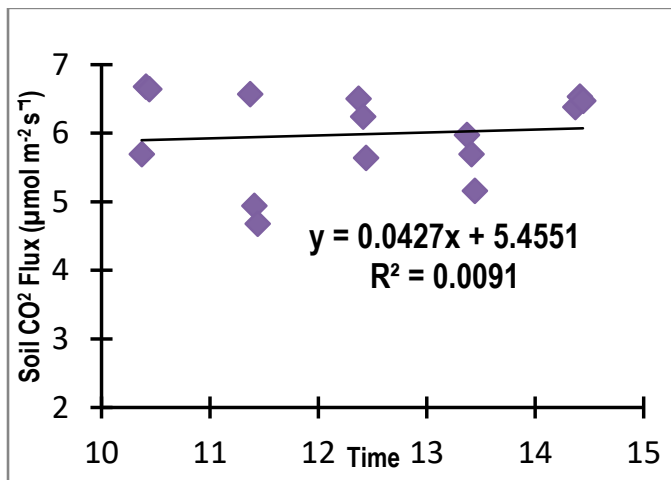

Figure 5 - Soil $\mathrm{CO}_{2}$ Flux at plot 70

(01.09.2016)

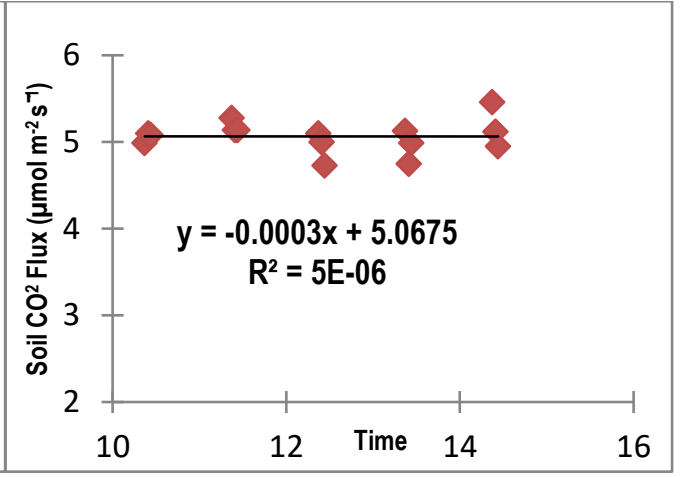

Figure 4 - Soil $\mathrm{CO}_{2}$ Flux at plot 151

(24.08.2016)

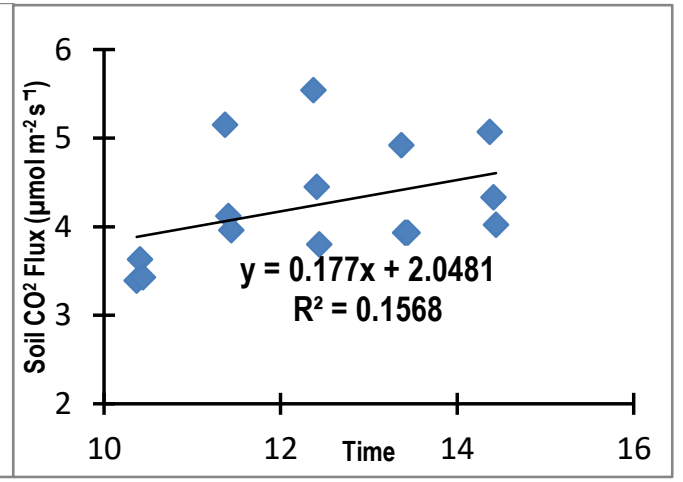

Figure 6 - Soil $\mathrm{CO}_{2}$ Flux at plot 68

$(10.09 .2016)$ 


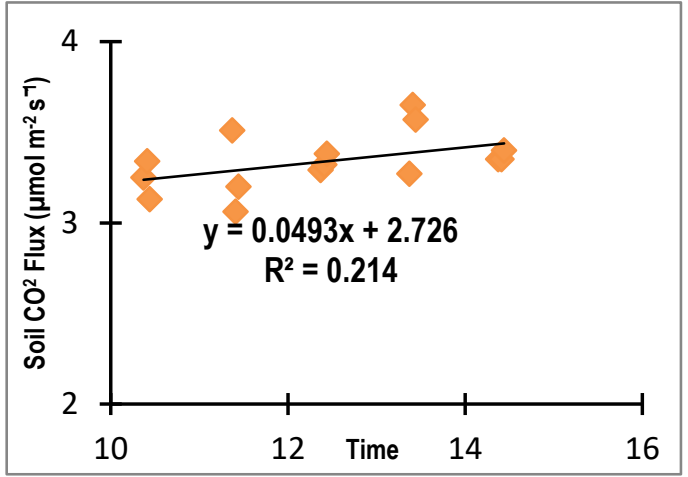

Figure 7 - $\mathrm{Soil} \mathrm{CO}_{2}$ Flux at plot 151

$(15.09 .2016)$

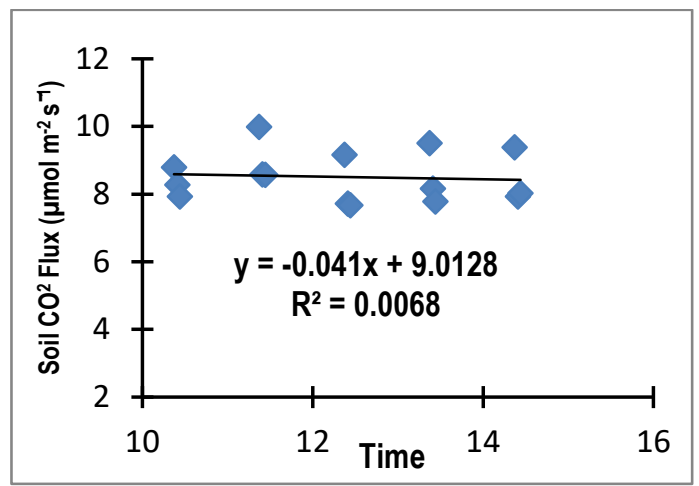

Figure 9 - Soil $\mathrm{CO}_{2}$ Flux at plot 68

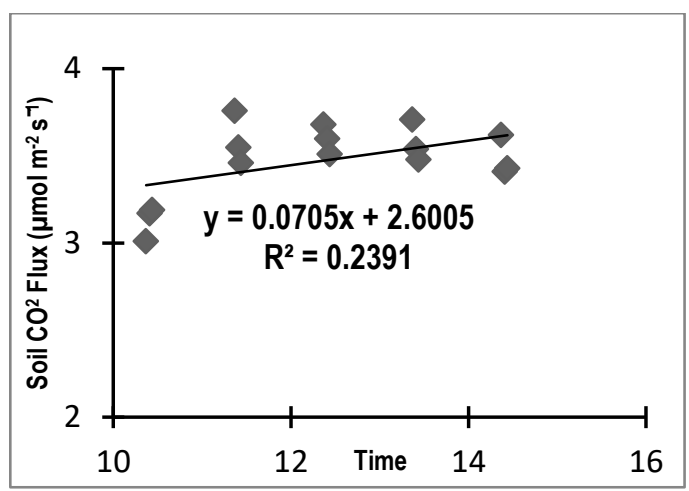

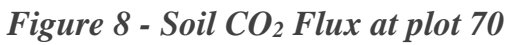

(24.09.2016)

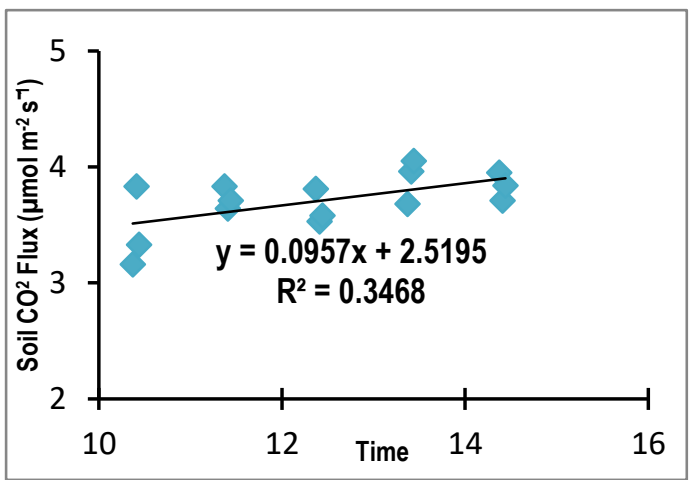

Figure 10 - Soil $\mathrm{CO}_{2}$ Flux at plot 151

$(08.10 .2016)$

$(01.10 .2016)$

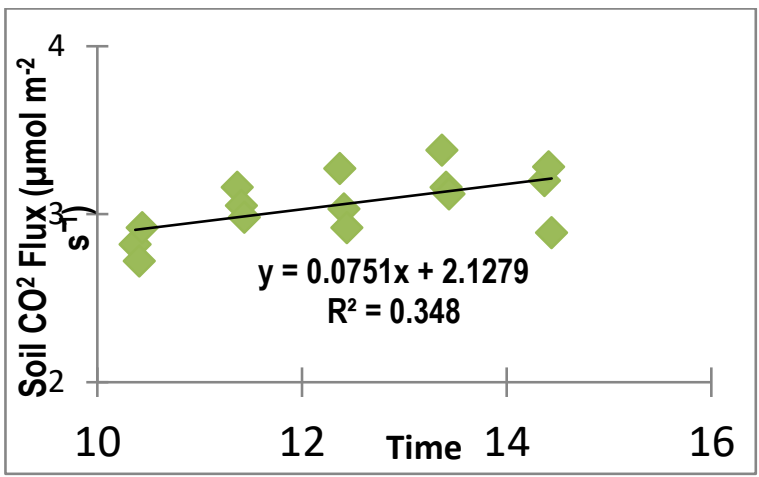

Figure 11 - $\mathrm{Soil} \mathrm{CO}_{2}$ Flux at plot 70 (15.10.2016)

\section{Conclusion}

In conclusion, this study showed that the soil $\mathrm{CO}_{2}$ efflux varied depends on the environmental factors such as soil temperature and soil relative humidity, thus influenced the microbial activity. The average soil $\mathrm{CO}_{2}$ efflux in this area was $4.68 \mu \mathrm{mol} \mathrm{m} \mathrm{m}^{-2} \mathrm{~s}^{-1}$. Temperature started to increased and influenced the soil $\mathrm{CO}_{2}$ efflux to increase. In addition, soil temperature was the main factor that influenced soil respiration compared to soil relative humidity. 


\section{Acknowledgements}

This study was funded us MOHE FRGS grant No. 07-01-15-1748FR.

\section{References}

Ainuddin, N. A., \& Goh, K. (2010). Effect of forest fire on stand structure in raja musa peat swamp forest reserve, Selangor, Malaysia. Journal of Environmental Science and Technology, 3(1), 56-62.

Ekblad, A., \& Hogberg, P. (2001). Natural abundance of 13C in CO2 respired from forest soils reveals speed of link between tree photosynthesis and root respiration. Oecologia, 127(3), 305-308.

Miettinen, J. and Liew, S.C (2010). Degradation and development of peatlands in peninsular Malaysia and in the islands of Sumatra and Borneo, Land Degrad. Dev., 21, 285-296.

Syaufina, L., Nuruddin, A. A., Basharuddin, J., See, L. F., \& Yusof, M. R. M. (2004). The effects of climatic variations on peat swamp forest condition and peat combustibility. Jurnal Manajemen Hutan Tropika, 10(1). 